\title{
Poly- $\beta$-hydroxybutyrate (PHB) biosynthetic genes in Rhizobium meliloti 41
}

\author{
Riccardo Tombolini, ${ }^{1}$ Silvana Povolo, ${ }^{1}$ Alberto Buson, ${ }^{1}$ Andrea Squartini ${ }^{2}$ \\ and Marco P. Nuti
}

1 CRIBI Biotechnology Center, Università di Padova, Italy

2 Dipartimento di Biotecnologie Agrarie, Università di Padova, Via Gradenigo 6, 35131 Padova, Italy
Author for correspondence: Marco P. Nuti. Tel. +39 49 8071442/8071385. Fax +39498070517. e-mail: biotmpn@ipdunidx.unipd.it

Genes encoding $\beta$-ketothiolase (phaA), acetoacetyl-CoA reductase (phaB) and PHB-synthase (phaC) from $R$. meliloti 41, together with a fourth gene, referred to as ORF1, presumed to be involved in PHB biosynthesis, have been cloned and sequenced. phaA, phaB and ORF1 were identified by heterologous hybridization on a cosmid library, while phaC was isolated by cloning the transposon-tagged fragment from a R. meliloti PHB- Tn5 mutant. phaA and phaB were functionally expressed in Escherichia coli while phaC was able to complement a PHB- strain of $R$. meliloti 41. The three genes were sufficient to direct the production of polyhydroxyalkanoate in $E$. coli. The homology of ORF1 with an ORF located near the PHB genes in two phototrophic bacteria suggests its involvement in PHB synthesis.

Keywords: Rhizobium meliloti, poly- $\beta$-hydroxybutyrate, $p h a A$, phaB, phaC

\section{INTRODUCTION}

In the last two decades much research has been done on polyesters synthesized and accumulated by microorganisms belonging to diverse taxonomic groups (Anderson \& Dawes, 1990; Steinbüchel, 1991). Natural polymers exist in which tens of hydroxyalkanoic acids have been detected. The chemical family that groups all these polymers is that of the polyhydroxyalkanoic acids (PHA). In this paper we refer to PHB as a PHA whose monomers are hydroxybutyric acid and/or hydroxyvaleric acid. The thermoplastic properties of some of these polymers have given rise to great scientific and industrial interest. Rbizobium species accumulate PHB as reserve material (Forsyth et al., 1958; Tombolini \& Nuti, 1989). In the bacterial cells this polymer functions as a carbon storage compound or as a sink for reducing equivalents. Rbizobium has not yet been thoroughly investigated as a potential PHA producer for industrial purposes. It has been suggested that PHB in Rhizobium bacteroids may play an important role in nitrogen fixation efficiency (Wong \& Evans, 1971; Kretovich et al., 1977; Romanov et al., 1980; Bergersen et al., 1991; Bergersen \& Turner, 1992, 1993). Controlled utilization of PHB in bacteroids may sustain $\mathrm{N}_{2}$-fixation under suboptimal

Abbreviations: PHA, polyhydroxyalcanoate; PHB, polyhydroxybutyrate. The GenBank accession numbers for the sequences reported in this paper are U17226 and U17227. plant carbon supply conditions (Bergersen \& Turner, 1992). The genetics of PHA production has been in part elucidated; the Alcaligenes eutrophus operon containing $p h a C$ (PHB synthase), pha $A$ ( $\beta$-ketothiolase, EC 2.3.1.16) and $p b a B$ (NADPH-dependent acetoacetylCoA reductase, EC 1.1.1.36) when expressed in Escherichia coli enables the formation of PHB granules indistinguishable from those found in the original host (Schubert et al., 1988; Slater et al., 1988; Peoples \& Sinskey, 1989a, b). In addition, the following genes have been cloned and sequenced from other bacteria: $p h a A, B$, $C$ from Cbromatium vinosum (Liebergesell \& Steinbüchel, 1992) and Acinetobacter sp. (Schembri et al., 1994a, b); phaA, C from Thiocystis violacea (Liebergesell \& Steinbüchel, 1993); phaC from Rhodobacter sphaeroides (Hustede et al., 1992; Hustede \& Steinbüchel, 1993), Metbylobacterium extorquens (Valentin \& Steinbüchel, 1993) and Rhodococcus ruber (Pieper \& Steinbüchel, 1992); and pha A, B from Zoogloea ramigera (Peoples et al., 1987; Peoples \& Sinskey, 1989c). In some instances, a fourth gene, $p h a E$, has been demonstrated to be required for PHA synthesis. It was found in Chromatium vinosum and Tbyocystis violacea and is involved in the polymerization step of PHA biosynthesis (Liebergesell \& Steinbüchel, 1992, 1993; Liebergesell et al., 1992). Recently the product of an ORF in the PHA synthase gene locus of Rbodococcus ruber was identified as a protein present on the granule surface (Pieper-Fürst $e t$ al., 1994). The finding of PHA leaky mutants that map in genes not directly involved in PHB biosynthesis (Pries et al., 1991, 1992) and the 
presence of ORFs structurally linked to $p h a A, p h a B$ and phaC (Steinbüchel et al., 1992) indicate the possible involvement of additional genes. In a previous report (Povolo et al., 1994) we described the isolation and analysis of Rbizobium meliloti PHB mutants carrying a Tn 5 in the synthase gene. The present study reports the cloning and characterization of the genes involved in PHB biosynthesis in this species.

\section{METHODS}

Bacterial strains and plasmids. Rhizobium meliloti and Escherichia coli strains, and plasmids, used in this study are listed in Table 1.

Growth conditions. R. meliloti was grown at $30^{\circ} \mathrm{C}$ in YMB medium (per litre: $0.5 \mathrm{~g} \mathrm{~K}_{2} \mathrm{HPO}_{4}, 0.2 \mathrm{~g} \mathrm{MgSO}_{4} .7 \mathrm{H}_{2} \mathrm{O}, 0.1 \mathrm{~g}$ $\mathrm{NaCl}, 10.0 \mathrm{~g}$ mannitol, 0.4 g yeast extract; $\mathrm{pH} 6.8$ ), TY medium (per litre: $5.0 \mathrm{~g}$ tryptone, $3.0 \mathrm{~g}$ yeast extract, $0.9 \mathrm{~g} \mathrm{CaCl}_{2} .2 \mathrm{H}_{2} \mathrm{O}$;

Table 1. Bacterial strains and plasmids

\begin{tabular}{|c|c|c|}
\hline $\begin{array}{l}\text { Strain or } \\
\text { plasmid }\end{array}$ & Relevant traits & Reference/origin \\
\hline \multicolumn{3}{|l|}{ Bacteria } \\
\hline R. meliloti $41^{*}$ & Wild-type & $\begin{array}{l}\text { Prakash et al. } \\
(1980)\end{array}$ \\
\hline $\begin{array}{l}\text { R. meliloti } \\
\text { 41011* }\end{array}$ & $\begin{array}{l}\mathrm{PHB}^{-} \text {mutant of } \\
\text { R. meliloti } 41\end{array}$ & $\begin{array}{l}\text { Povolo et al. } \\
\text { (1994) }\end{array}$ \\
\hline E. coli LE392 & Host for cosmid library & Borck et al. (1976) \\
\hline E. coli JM109 & $\sup E \operatorname{supF}$ lac $Y 1 \operatorname{rec} A 1$ & $\begin{array}{l}\text { Yanisch-Perron } \\
\text { et al. (1985) }\end{array}$ \\
\hline E. coli $\mathrm{S} 17-1$ & $\begin{array}{l}\text { Mobilizing donor strain, } \\
\operatorname{Tra}^{+} \text {pro } \operatorname{rec} A\end{array}$ & $\begin{array}{l}\text { Simon et al. } \\
\text { (1983) }\end{array}$ \\
\hline \multicolumn{3}{|l|}{ Plasmids } \\
\hline pHC79 & $A p^{r}, \cos$ & $\begin{array}{l}\text { Hohn \& Collins } \\
(1980)\end{array}$ \\
\hline pSF6 & $\begin{array}{l}\mathrm{Sp}^{\mathrm{r}} \mathrm{Sm}^{\mathrm{r}}, \mathrm{Mob}^{+}, \mathrm{IncW}, \\
\cos \end{array}$ & $\begin{array}{l}\text { Selvaraj et al. } \\
\text { (1984) }\end{array}$ \\
\hline pTZ19R & $\begin{array}{l}\text { Ap } \mathrm{r}, \mathrm{T} 7 \text {-lac tandem } \\
\text { promoters, } \alpha \text {-lac } Z\end{array}$ & Mead et al. (1986) \\
\hline pTZK19R & pTZ19R $+\mathrm{Km}^{\mathrm{R}}$ cassette & This study \\
\hline pMP220 & $\begin{array}{l}\mathrm{Tc}^{\mathrm{r}}, \text { 'lac } Z, \text { promoter } \\
\text { probe, IncP }\end{array}$ & $\begin{array}{l}\text { Spaink et al. } \\
\text { (1987) }\end{array}$ \\
\hline pCDP1 & $\begin{array}{l}\text { Cosmid from R. meliloti } \\
41 \text { library in pHC79 }\end{array}$ & This study \\
\hline pCDP2 & $\begin{array}{l}\text { Cosmid from R. meliloti } \\
41 \text { library in pHC79 }\end{array}$ & This study \\
\hline pTZ-HX400 & $\begin{array}{l}\text { pba } A, \text { phaB of } \mathrm{R} . \text { meliloti } \\
41 \text { in } \mathrm{pTZ19R}\end{array}$ & This study \\
\hline pTZ-ORF1 & $\begin{array}{l}\text { ORF1 of R. meliloti } 41 \\
\text { in pTZ19R }\end{array}$ & This study \\
\hline $\mathrm{pS} 600$ & $\begin{array}{l}\text { phaC of R. meliloti } 41 \text { in } \\
\text { pMP220 }\end{array}$ & This study \\
\hline pTZ18U-PHB & $\begin{array}{l}\text { pha } A, p b a B, p b a C \text { of } \\
\text { A. eutrophus containing } \\
\text { insert }\end{array}$ & $\begin{array}{l}\text { E. Dennis, } \\
\text { Biology Dept, } \\
\text { James Madison } \\
\text { University }\end{array}$ \\
\hline
\end{tabular}

* The renaming of Rhizobium meliloti as Sinorbizobium meliloti has recently been proposed (De Lajudie et al., 1994).
$\mathrm{pH}$ 6.8) or RMM medium (per litre: $2.05 \mathrm{~g} \mathrm{~K}_{2} \mathrm{HPO}_{4}, 1.45 \mathrm{~g}$ $\mathrm{KH}_{2} \mathrm{PO}_{4}, 0.50 \mathrm{~g} \mathrm{MgSO}_{4} .7 \mathrm{H}_{2} \mathrm{O}, 0.15 \mathrm{~g} \mathrm{NaCl}, 0.01 \mathrm{~g} \mathrm{CaCl}_{2}$, $0.5 \mathrm{~g} \mathrm{NH}_{4} \mathrm{NO}_{3}, 2.0 \mathrm{~g}$ sucrose, $2.5 \mathrm{mg} \mathrm{FeSO}{ }_{4} .7 \mathrm{H}_{2} \mathrm{O}, 0.5 \mathrm{mg}$ $\mathrm{MnSO}_{4} \cdot \mathrm{H}_{2} \mathrm{O}, 0.5 \mathrm{mg} \mathrm{ZnSO}{ }_{4} .7 \mathrm{H}_{2} \mathrm{O}, 0.5 \mathrm{mg} \mathrm{CuSO}{ }_{4} .5 \mathrm{H}_{2} \mathrm{O}$, $0.5 \mathrm{mg} \mathrm{H}_{3} \mathrm{BO}_{3}, 0.5 \mathrm{mg} \mathrm{NaMoO}, 0.01 \mathrm{mg}$ biotin, $0.01 \mathrm{mg}$ calcium-pantothenate, $0.01 \mathrm{mg}$ thiamin). When required, antibiotics were added at the following concentrations: $50 \mu \mathrm{g}$ kanamycin $\mathrm{ml}^{-1}, 100 \mu \mathrm{g}$ rifampicin $\mathrm{ml}^{-1}$. E. coli was grown at $37^{\circ} \mathrm{C}$ in LB medium (Sambrook et al., 1989), supplemented with antibiotics as appropriate $\left(20 \mu \mathrm{g}\right.$ ampicillin $\mathrm{ml}^{-1}, 30 \mu \mathrm{g}$ kanamycin ml ${ }^{-1}, 10 \mu \mathrm{g}$ tetracycline $\left.\mathrm{ml}^{-1}\right)$. Media were solidified by the addition of $1.5 \%(\mathrm{w} / \mathrm{v})$ agar. Liquid cultures were stirred at 100 r.p.m.

DNA isolation and manipulation. Plasmid DNA was prepared from crude lysates by alkaline extraction (Sambrook et al., 1989). DNA fragments were isolated from agarose gels using a gel extraction kit (Qiaex, Qiagen). Cosmid DNA was digested with restriction endonucleases as described by the manufacturer. DNA restriction fragments were separated on $0.7 \%(\mathrm{w} / \mathrm{v})$ agarose gels in TAE buffer $(0.04 \mathrm{M}$ Tris/acetate, $0.001 \mathrm{M}$ EDTA, pH 8.0). Transfer of DNA to nylon membranes (Hybond-N nylon membrane, Amersham) was carried out as described by the manufacturer. DNA was digoxigenin-labelled and non-isotopic hybridizations were subsequently carried out using the Dig DNA Labeling and Detection Kit (Boehringer Mannheim) as described by the manufacturer.

DNA transfers. Transformation of $E$. coli was done by electroporation as described by Dower $e$ t al. (1988) with the $E$. coli Pulser Apparatus set at $2.5 \mathrm{kV}$ using $0.2 \mathrm{~cm}$ gap cuvettes. Conjugations were performed on solidified LB (between E. coli strains) or TY (between E. coli and R. meliloti). After $24 \mathrm{~h}$ incubation at $37^{\circ} \mathrm{C}$ or $30^{\circ} \mathrm{C}$ respectively, cells were resuspended in saline solution $\left(0.9 \mathrm{~g} \mathrm{NaCl} \mathrm{l}^{-1}\right)$ and dilutions were plated on selective media.

Cosmid library construction and screening. A cosmid DNA library from R. meliloti 41 was made as follows. Total DNA was extracted (Meade et al., 1982) and partially digested with BamHI. Phenol/chloroform-purified fragments were dephosphorylated using alkaline phosphatase and subsequently ligated to BamHIdigested cosmid pHC79 or pSF6 at a ratio of 10:1. The ligated DNA was packaged with $\lambda$ coat proteins by using the Boehringer Mannheim DNA Packaging Kit and transfected into E. coli LE392 as described by Hohn (1979) and Hohn \& Collins (1980). Cells were plated onto LB-agar containing ampicillin (for $\mathrm{pHC79}$ ) or spectinomycin (for $\mathrm{pSF}$ ). Genomic libraries from R. meliloti $\mathrm{PHB}^{-}$( $\mathrm{Tn} 5$-induced) mutants (Povolo et al., 1994) were constructed in the same way. After transfection, cells were plated onto LB-agar containing ampicillin and kanamycin to select for inserts bearing the $\operatorname{Tn} 5$ insertion. Libraries were screened by hybridization. Colonies were transferred to Hybond-N nylon membranes (Amersham) as described by the manufacturer. DNA was labelled with digoxigenin and hybridization was performed as described above at $68^{\circ} \mathrm{C}$ with $0.1 \times$ SSC final wash (homologous probes) or at $58^{\circ} \mathrm{C}$ with $0.5 \times$ SSC final wash (heterologous probes).

Sequencing and analysis of sequence data. Dideoxy nucleotide sequencing was carried out from double-stranded DNA using the Applied-Biosystems Taq DyeDeoxy Cycle Sequencing Kit in a thermal cycler with the temperature programme suggested by the manufacturer. An automatic DNA sequencer (model 370A, Applied Biosystems) was used. Sequences of both strands were obtained from restriction fragments subcloned in pTZ19R using universal primers. Additional sequences were obtained by using custom-made synthetic primers. Sequences were processed and analysed by the IG Molecular Biology Software System, release 5.4 (IntelliGenetics). Homology 
searches in the GenBank and SwissProt databases were made with the FASTA and TFASTA programs. Comparisons of amino acid sequences were made with the specific programs included in the PCGENE collection, release 6.0 (IntelliGenetics and Genofit).

Biochemical analytical procedures. Cell extracts for enzyme assays were obtained by the following procedure. Samples $(300 \mathrm{ml}$ of $\mathrm{R}$. meliloti or $10 \mathrm{ml}$ of E. coli) of late-exponentialphase cultures were centrifuged at $4000 \mathrm{~g}$ for $15 \mathrm{~min}$ at $4{ }^{\circ} \mathrm{C}$. For the $\beta$-ketothiolase and acetoacetyl-CoA reductase assay, the pellet was resuspended in $2 \mathrm{ml}$ of the following buffer: $10.0 \mathrm{mM}$ Tris/ $\mathrm{HCl} \mathrm{pH} \mathrm{7.88,5.0} \mathrm{mM} \mathrm{EDTA,} 5.0 \mathrm{mM} \beta$-mercaptoethanol, $0.02 \mathrm{mM}$ PMSF (phenylmethylsulfonyl fluoride), $5 \%(\mathrm{v} / \mathrm{v})$ glycerol. The suspension was sonicated by using a microprobeequipped model 450 sonicator (Branson Ultrasonic Corporation) in an ice-water bath for 20 min with pulses of $0.5 \mathrm{~s}$ at $50 \%$ duty cycle. The extract was centrifuged for $10 \mathrm{~min}$ at $10000 \mathrm{~g}$ at $4{ }^{\circ} \mathrm{C}$. The supernatant was kept on ice until analysis. Protein content was quantified by using the Coomassie Plus Protein Assay Reagent Kit (Pierce) calibrated with bovine serum albumin. The $\beta$-ketothiolase (thiolysis reaction) and acetoacetylCoA reductase assays were conducted as described by Senior \& Dawes (1971) and Haywood et al. (1988), respectively. PHB content in bacterial cells was measured as described by Braunegg et al. (1978). A model 8420 capillary gas-chromatograph (PerkinElmer) with a WCOT fused silica capillary column and CPWAX-58 CB liquid phase (Chrompack) was used. Working conditions have already been reported (Povolo et al., 1994).

\section{RESULTS AND DISCUSSION}

\section{Cloning and sequencing of phaA and phaB}

A cosmid genomic library of R. meliloti 41 in pHC79 was screened by colony hybridization with a probe containing the $p h a C, p h a A$ and $p h a B$ genes from Alcaligenes eutropbus (Slater et al., 1988). Under low-stringency conditions two clones were isolated, containing plasmids pCDP1 and pCDP2. Plasmid pCDP1 contained three Bam HI fragments of about 4300,1700 and 300 bp respectively which hybridized with the $A$. eutrophus probe. pCDP2 shares with pCDP1 the $4300 \mathrm{bp} \mathrm{BamHI}$ hybridizing fragment. In Fig. 1(a) the physical and genetic map of the cloned region, as determined by nucleotide sequencing, is shown. The 4300 bp Bam HI fragment common to PCDP1 and pCDP2 is the one between the first two BamHI sites on the left in Fig. 1(a), including ORF1 and part of phaA.

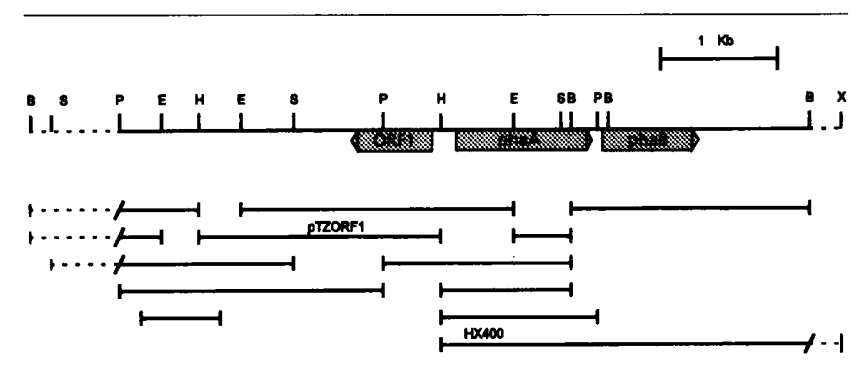

Fig. 1. (a) Physical and genetic map of the cloned region containing the phaA and phaB genes and ORF1. The solid line represents the sequenced DNA. Dotted lines encompass region not drawn to scale. B, BamHI; S, Sacl; P, Pstl; H, HindIII; E, EcoRI, $X$, Xhol. (b) Subcloning strategy. Fragments labelled pTZORF1 and HX400 were used in expression studies.

\section{Analysis of the sequence containing phaA and phaB}

The presence of the pha $A$ and $p h a B$ genes in the sequenced region was indicated on the basis of DNA homology. However pCDP1, containing the sequenced region, conferred neither $\beta$-ketothiolase nor acetoacetyl-CoA reductase activities upon $E$. coli (see Table 4 ). Amino acid sequences deduced from the ORFs of the region showing homology with $p h a A$ and $p h a B$ genes were compared with those from published nucleotide sequences of $\beta$-ketothiolase and acetoacetyl-CoA reductase (Tables 2 and 3 ). In Table 2 , as well as sequences of $\beta$-ketothiolases from PHB producers (shown in bold type), some from nonPHB-producing organisms have been included, to point out the much higher level of homology found between the sequenced $p h a A$ gene and members of the former group. It is apparent that the sequenced region of $R$. meliloti codes for these two enzymes. The products of $p h a A$ and $p h a B$ exhibit homology ranging from 59 to $68 \%$ with corresponding gene products in $A$. eutrophus, $C$. vinosum and $T$. violacea, and a remarkably high homology with the corresponding proteins in $Z$. ramigera $(88$ and $86.7 \%$ identity for $\beta$-ketothiolase and acetoacetyl-CoA reductase respectively). However, the high DNA homology with the corresponding genes in $Z$. ramigera extends into the pha $A$ upstream region (Fig. 2) covering the putative promoter structure. In $R$. meliloti the distance from this site and the $p h a A$ translational start point is about 50 nucleotides shorter. The bacterial strain known as I-16-M was originally identified as Zoogloea ramigera but it is clear from analysis of $16 \mathrm{~S}$ ribosomal RNA sequences (Shin $e t$ al., 1993) that the strain does not belong to the genus Zoogloea. Strain I-16-M is in fact related to Agrobacterium and Rhizobium, although its exact identity has not been established. Our results indeed suggest a close relation between Rhizobium and ' $Z$. ramigera' I-16-M.

Another open reading frame (ORF1) immediately upstream of the $p h a A-p h a B$ genes, but coded in the opposite direction, is homologous to a sequence (ORF4) related to PHB biosynthesis in Cbromatium vinosum and Thiocystis violacea (Liebergesell \& Steinbüchel, 1992, 1993). In these photosynthetic bacteria ORF4 is located between the pha $A$ and $p h a B$ genes. Comparison of the two amino acid sequences by the method proposed by Needleman \& Wunsch (1970) gave an alignment score of $13 \cdot 8$. This value is considerably higher than the score (i.e. 3 ) often used as cut-off point to indicate probable relatedness. In Fig. 3 the amino acid sequences of ORF1 in R. meliloti and ORF4 in C. vinosum are compared. The results show an identity of $40.5 \%$ and a similarity of $11 \cdot 8 \%$. Beyond the stop codon of ORF1 in R. meliloti there are 10 amino acids showing remarkable homology with the last amino acids of ORF 4 of $C$. vinosum. It could be inferred that the stretch of residues from positions 151 and 192 in ORF1, having no match in the corresponding $C$. vinosum sequence, arose from a DNA insertion bearing a stop codon at position 194. A codon usage analysis was carried out for ORF1 to compare frequencies with those of $18 \mathrm{R}$. meliloti genes in the GenBank database. The data matched the most frequent choices on almost all residues, suggesting a genuine coding nature for the frame identified. Fur- 


\section{Table 2. Homology of $\beta$-ketothiolases}

The data show the percentage of identical and similar (in parentheses) amino acids of the known $\beta$-ketothiolases (EC 2.3.1.16) (f, i) or acetoacetyl-CoA thiolases (EC 2.3.1.9) (a, b, c, d, e, g, h, i, k, l). 'Similar' indicates those residues which can be generally interchanged without modifying the conformation of a protein, that is: A-S-T; D-E; N-Q; R-K; I-L-M-V; F-Y-W. The amino acid sequences have been deduced from published nucleotide sequences of Zoogloea ramigera (Peoples et al., 1987), Alcaligenes eutropbus (Peoples \& Sinskey, 1989b), Chromatium vinosum (Liebergesell \& Steinbüchel, 1992), Thyocystis violacea (Liebergesell \& Steinbüchel, 1993), Escherichia coli (Yang et al., 1990), Rattus norvegicus (Arakawa et al., 1987), Saccharomyces uvarum (Dequinn et al., 1988), Candida tropicalis (Kurihara et al., 1992), Saccharomyces cerevisiae (Hiser et al., 1993), Raphanus sativus (Vollack et al., 1994) and Homo sapiens (Fukao, et al., 1990). The data in bold type are from PHB-producing organisms.

\begin{tabular}{|c|c|c|c|c|c|c|c|c|c|c|c|c|c|}
\hline & & (a) & (b) & (c) & (d) & (e) & (f) & (g) & (h) & (i) & (i) & (k) & (1) \\
\hline R. meliloti & (a) & 100 & $88.0(5 \cdot 1)$ & $63 \cdot 4(11 \cdot 7)$ & $62 \cdot 6(14 \cdot 0)$ & $61.3(14.8)$ & $43 \cdot 4(13 \cdot 4)$ & $43 \cdot 3(14 \cdot 0)$ & $42 \cdot 7(13 \cdot 7)$ & $40 \cdot 2(15 \cdot 5)$ & $41 \cdot 7(17 \cdot 6)$ & $42.5(15.5)$ & $39 \cdot 4(14.8)$ \\
\hline Z. ramigera & (b) & & 100 & $63.2(11 \cdot 5)$ & $60 \cdot 4(16 \cdot 1)$ & $59.6(16.1)$ & $41 \cdot 9(12 \cdot 4)$ & $41 \cdot 2(15 \cdot 6)$ & $40 \cdot 4(15 \cdot 6)$ & $40 \cdot 2(14 \cdot 1)$ & $39.6(17.6)$ & $41.4(15.9)$ & $34 \cdot 3(16 \cdot 1)$ \\
\hline A. eutropbus & (c) & & & 100 & $67 \cdot 9(13 \cdot 2)$ & $68.7(13.5)$ & $42 \cdot 9(15 \cdot 8)$ & $43 \cdot 8(15 \cdot 0)$ & $45 \cdot 0(14 \cdot 0)$ & $45 \cdot 3(13 \cdot 7)$ & $41.5(17.6)$ & $44 \cdot 8(15 \cdot 5)$ & $39 \cdot 4(13.2)$ \\
\hline C. vinosum & (d) & & & & 100 & $87 \cdot 3(6 \cdot 6)$ & $44 \cdot 4(12 \cdot 4)$ & $43.1(16 \cdot 8)$ & $43.7(15.7)$ & $42.6(15 \cdot 7)$ & $41.6(17.5)$ & $39.6(18.3)$ & $38.8(14.2)$ \\
\hline T. violacea & (e) & & & & & 100 & $45.0(13 \cdot 7)$ & $40.9(17.0)$ & $41.4(16.0)$ & $42.6(15.5)$ & $41.6(17.0)$ & $40.9(18.3)$ & $37 \cdot 1(15 \cdot 7)$ \\
\hline E. coli & (f) & & & & & & 100 & $33 \cdot 1(13 \cdot 2)$ & $33 \cdot 3(12 \cdot 9)$ & $37.0(14 \cdot 0)$ & $39 \cdot 3(10 \cdot 3)$ & $34 \cdot 6(14 \cdot 7)$ & $31 \cdot 8(9 \cdot 8)$ \\
\hline S. uvarum & (g) & & & & & & & 100 & $95.5(2 \cdot 8)$ & $65 \cdot 6(13 \cdot 3)$ & $38.8(14.9)$ & $49.5(13.6)$ & $46.5(13.1)$ \\
\hline S. cerevisiae & (h) & & & & & & & & 100 & $66 \cdot 6(12 \cdot 8)$ & $39 \cdot 5(14 \cdot 1)$ & $49 \cdot 2(13 \cdot 6)$ & $47 \cdot 0(13 \cdot 3)$ \\
\hline $\begin{array}{l}\text { C. tropicalis } \\
\text { (peroxisomal) }\end{array}$ & (i) & & & & & & & & & 100 & $34 \cdot 8(18 \cdot 1)$ & $48 \cdot 4(14 \cdot 1)$ & $46.9(14 \cdot 4)$ \\
\hline $\begin{array}{l}\text { R. norvegicus } \\
\text { (mitochondrial) }\end{array}$ & (j) & & & & & & & & & & 100 & $38.8(15.6)$ & $33 \cdot 3(12 \cdot 3)$ \\
\hline $\begin{array}{l}\text { H. sapiens } \\
\text { (liver, } \\
\text { mitochondrial) }\end{array}$ & (k) & & & & & & & & & & & 100 & $43.8(14 \cdot 6)$ \\
\hline $\begin{array}{l}\text { R. sativus } \\
\text { (seedling) }\end{array}$ & (l) & & & & & & & & & & & & 100 \\
\hline
\end{tabular}

Table 3. Homology of acetoacetyl-CoA reductase

Data are expressed as in Table 2. The sources of nucleotide sequences are the same as in Table 2 except for $Z$. ramigera (Peoples \& Sinskey, 1989).

\begin{tabular}{|llcccc|}
\hline & & (a) & (b) & (c) & (d) \\
\hline R. meliloti & (a) & $100 \cdot 0$ & $86 \cdot 7(6 \cdot 6)$ & $51 \cdot 0(13 \cdot 3)$ & $50 \cdot 6(14 \cdot 1)$ \\
$\begin{array}{l}\text { Z. ramigera } \\
\text { (b) }\end{array}$ & & $100 \cdot 0$ & $52 \cdot 3(13 \cdot 3)$ & $51 \cdot 5(14 \cdot 1)$ \\
A. eutrophus (c) & & & $100 \cdot 0$ & $56 \cdot 1(14 \cdot 6)$ \\
C. vinosum & (d) & & & & $100 \cdot 0$ \\
\hline
\end{tabular}

R.m. GCAACTAGCCGTTTEACTCGCGCTCCTCC-CTTTGCCAGTCT-1-10-GC 43 z.r. GGGATATCCCGTTIAACTCTC-CTTCTCCGCTTTGCCAGTITTGATTTCGGGAGAACCGC 59

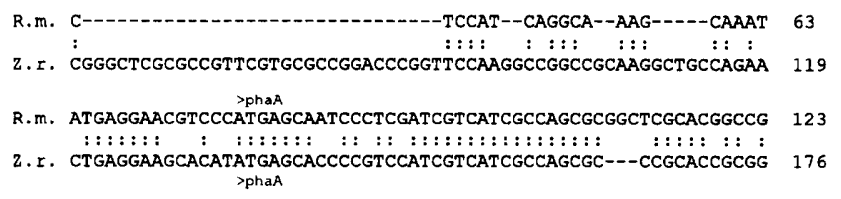

Fig. 2. Alignment of the nucleotide sequences of the corresponding -10 and -35 putative promoter (in boldface) regions of the phaA-phaB operon in Zoogloea ramigera (Peoples \& Sinskey, 1989) with the homologous R. meliloti sequence. The asterisk indicates the transcriptional start site in Z. ramigera.

thermore ORF1 was shown to be expressible in E. coli when cloned in PTZ19R, giving rise to an additional protein band of about $22 \mathrm{kDa}$, when cell lysates of

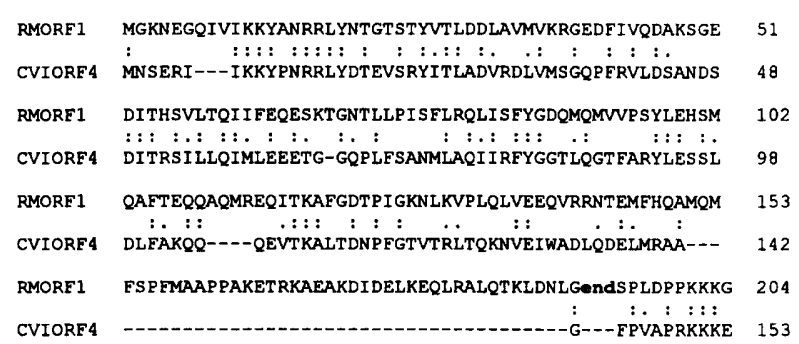

Fig. 3. Alignment of the amino acid sequences of ORF4 of Chromatium vinosum and ORF1 of $R$. meliloti deduced from the nucleotide sequences. The two ORFs display $37.3 \%$ identity (:) and $11.8 \%$ similarity (.). The 10 hypothetical residues past the stop codon (end) in $R$. meliloti ORF1 are reported to show homology with the C-terminal part of the $C$. vinosum ORF4 product.

JM109(pTZ19R) and JM109(pTZORF1) were compared by SDS-PAGE. The molecular mass observed was in agreement with that expected from the deduced amino acid sequence of ORF1.

\section{Heterologous expression of phaA and phaB}

$\beta$-Ketothiolase and acetoacetyl-CoA reductase activities could not be detected in $E$. coli containing pCDP1, nor was PHB found (Table 4). In contrast, when the fragment indicated as HX400 in Fig. 1(b) was subcloned in pTZ19R with the $p h a A / B$ genes downstream of the T7-lac tandem vector promoters, both activities could be detected in $E$. coli JM109. In order to prove the involvement of pha $A$ and $p h a B$ in PHA synthesis, the two cloned genes carried by fragment HX400 were subcloned in pTZK19R, a 
Table 4. Expression of phaA and phaB

\begin{tabular}{|lll|}
\hline Strain & $\boldsymbol{\beta}$-Ketothiolase* & $\begin{array}{c}\text { Acetoacetyl-CoA } \\
\text { reductase* }\end{array}$ \\
\hline E. coli & & \\
JM109(pTZ-HX400) & $0 \cdot 13$ & $0 \cdot 29$ \\
E. coli JM109(pTZ19R) & $0 \cdot 007$ & $0 \cdot 00$ \\
R. meliloti 41 & $1 \cdot 2$ & $0 \cdot 047$ \\
E. coli LE392(pCDP1) & $0 \cdot 00$ & $0 \cdot 00$ \\
\hline
\end{tabular}

* Specific activity : units ( $\mathrm{mg}$ protein $)^{-1}$ [1 unit equals the amount of enzyme consuming $1 \mu \mathrm{mol}$ acetoacetyl-CoA $\min ^{-1}$ ( $\beta$-ketothiolase) or $1 \mu \mathrm{mol} \mathrm{NADPH} \min ^{-1}$ (acetoacetyl-CoA reductase)].

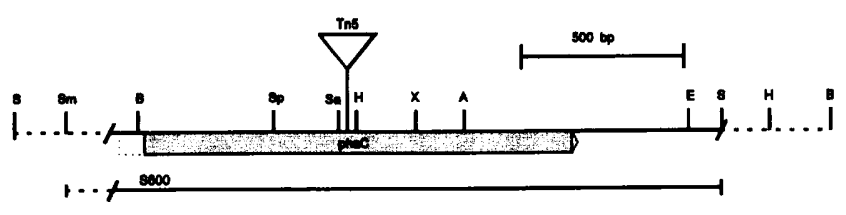

Fig. 4. Physical and genetic map of the cloned region containing phaC. The solid line represents the sequenced DNA. Dotted lines encompass regions not drawn to scale. S, Sacl; Sm, Smal; B, BamHI; Sp, Sphl; Sa, Sall; H, Hindlll; X, Xhol; A, Avill; $E, E C O R I$. The Smal-Sacl fragment labelled $S 600$ was used for complementation studies. The Tn5 insertion site in mutant $\mathbf{4 1 0 1 1}$ is indicated.

$\mathrm{Km}$-resistant derivative of pTZ19R, and introduced into E. coli JM109 containing phaC cloned in pTZ19R. Gas chromatographic analyses proved that the co-presence of $\beta$-ketothiolase, reductase and synthase led to the production of small but measurable amounts of PHA in $E$. coli when grown in the presence of $20 \mathrm{~g}_{\text {glucose }} \mathrm{l}^{-1}$ (data not shown). Controls containing either the $p h a C$ gene alone or the PTZ19R vector did not reveal polymer accumulation. These results confirm that $p h a A$ and $p h a B$ are necessary for PHA production.

\section{Cloning and sequencing of phaC}

A genomic cosmid library from R. meliloti 41011 , a PHB $^{-}$ mutant of $\mathrm{R}$. meliloti 41 obtained by $\operatorname{Tn} 5$ mutagenesis (Povolo et al., 1994), was made in pHC79. Using an internal HindIII fragment from $\operatorname{Tn} 5$ as a probe, a positive clone was detected by colony hybridization. Since $\operatorname{Tn} 5$ has no EcoRI sites and one BamHI site, regions flanking the insertion were identified in an $\mathrm{EcoRi}-\mathrm{Bam} \mathrm{HI}$ digest of the cosmid by hybridization with $\operatorname{Tn} 5$ and used as a probe to screen a pSF6 cosmid genomic library from the parental R. meliloti 41. A positive clone was identified and the restriction map of the region of interest was determined (Fig. 4); 2653 bases were sequenced.

\section{Nucleotide sequence analysis of phaC}

The sequence analysis showed the presence of the $p h a C$ gene on the basis of DNA homology with published sequences (Hustede et al., 1992; Valentin \& Steinbüchel,
1993; Pieper \& Steinbüchel, 1992; Liebergesell \& Steinbüchel, 1993). The highest homology at the amino acid level was found with the methylotrophic bacterium Metbylobacterium extorquens (Valentin \& Steinbüchel, 1993). The PHB synthase of $R$. meliloti 41 matches the consensus for those amino acid residues present in all PHB synthases involved in the biosynthesis of short-chain hydroxyalkanoic acids (Steinbüchel et al., 1992). As the Ntermini of the synthases show poor homology, the start codon was assigned on the basis of length comparison with other PHB synthases. An alternative but less likely GUG start codon lies 102 bp upstream of the proposed one.

\section{Complementation studies of phaC}

A $3 \mathrm{~kb} S m a \mathrm{I}-S a c \mathrm{I}$ fragment containing the $p h a C$ gene was blunt-ended at the $S a c \mathrm{I}$ terminus by Klenow DNA polymerase and subcloned into a blunt-ended BamHI site of the broad-host-range vector pMP220 yielding pS600 which, when transferred to $R$. meliloti 41011 , could complement the mutant's complete inability to accumulate PHB. The introduced plasmid led to the production of $31.9 \%$ ( $w / w$ of bacterial dry weight) PHB, a value close to the wild-type yield of $36 \cdot 2 \%$. Since pMP220 is a promoter-probe vector designed for LacZ assays and therefore devoid of any promoters acting on the polycloning site region, the expression of $p h a C$ which, moreover, occurs in both cloning orientations, indicates the presence of its own promoter within the $6 \mathrm{~kb} S a c \mathrm{I}$ fragment. This conclusion is further supported by the fact that $\beta$-galactosidase activity is obtained in R. meliloti only when the $p b b C$-containing fragment is cloned in the same orientation with respect to the reporter lac $Z$ gene. The same construct, however, does not confer a $\mathrm{LacZ}^{+}$ phenotype upon $E$. coli JM109, suggesting that the $R$. meliloti phaC promoter is not functional in this background.

\section{ACKNOWLEDGEMENTS}

Douglas E. Dennis (Department of Biology, James Madison University, Harrisonburg, VA 22807, USA) is gratefully acknowledged for providing the $A$. eutropbus DNA fragment containing $p h a A, p b a B$ and $p h a C$.

\section{REFERENCES}

Anderson, A. J. \& Dawes, E. A. (1990). Occurrence, metabolism, metabolic role, and industrial uses of bacterial polyhydroxyalkanoates. Microbiol Rev 54, 450-472.

Arakawa, H., Takiguchi, M., Amaya, Y., Nagata, S., Hayashi, H. \& Mori, M. (1987). cDNA-derived aminoacid sequence of rat mitochondrial 3-oxoacyl-CoA thiolase with no transient presequence: structural relationship with peroxisomal isoenzyme. EMBO J 6, 1361-1366.

Bergersen, F. J. \& Turner, G. L. (1992). Supply of $\mathrm{O}_{2}$ regulates $\mathrm{O}_{2}$ demand during utilization of reserves of poly- $\beta$-hydroxybutyrate in $\mathrm{N}_{2}$-fixing soybean bacteroids. Proc $\mathrm{R}$ Soc Lond Ser B 249, 143-148.

Bergersen, F. J. \& Turner, G. L. (1993). Effects of concentrations of substrates supplied to nitrogen-fixing soybean bacteroids in flow chamber reactions. Proc R Soc Lond Ser B 251, 95-102. 
Bergersen, F. J., People, M. B. \& Turner, G. L. (1991). A role for poly- $\beta$-hydroxybutyrate in bacteroids of soybean nodules. Proc $R$ Soc Lond Ser B 245, 59-64.

Borck, K., Beggs, J. D., Brammar, W. J., Hopkins, A. S. \& Murray, N. E. (1976). The construction in vitro of transducing derivatives of phage lambda. Mol \& Gen Genet 146, 199-207.

Braunegg, G., Sonnleitner, B. \& Lafferty, R. M. (1978). A rapid gas chromatographic method for the determination of poly- $\beta$-hydroxybutyric acid in microbial biomass. Eur J Appl Microbiol Biotecbnol 6, 29-37.

De Lajudie, P., Willems, A., Pot, B., Dewettinck, D., Maestrojuan, G., Neyra, M., Collins, M. D., Dreyfus, B., Kersters, K. \& Gillis, M. (1994). Polyphasic taxonomy of rhizobia: emendation of the genus Sinorbizobium and description of Sinorbizobium meliloti comb. nov., Sinorbizobium sabeli sp. nov., and Sinorbizobium teranga sp. nov. Int $J$ Syst Bacteriol 44, 715-733.

Dequinn, S., Gloeckler, R., Herbert, C. J. \& Boutlet, B. (1988). Cloning, sequencing and analysis of the yeast $S$. uvarum ERG10 gene encoding acetoacetyl-CoA thiolase. Curr Genet 13, 471-478.

Dower, W. J., Miller, J. F. \& Ragsdale, C. W. (1988). High efficiency transformation of E. coli by high voltage electroporation. Nucleic Acids Res 16, 6127.

Forsyth, G. C., Hayward, A. C. \& Roberts, J. B. (1958). Occurrence of poly- $\beta$-hydroxybutyric acid in aerobic Gram-negative bacteria. Nature 182, 800-801.

Fukao, T., Yamaguchi, S., Kano, M., Orii, T., Fujiki, Y., Osumi, T. \& Hashimoto, T. (1990). Molecular cloning and sequence of the complementary DNA encoding human mitochondrial acetoacetylcoenzyme A thiolase and study of the variant enzymes in cultured fibroblasts from patients with 3-ketothiolase deficiency. J Clin Invest 86, 2086-2092.

Haywood, G. W., Anderson, A. J., Chu, L. \& Dawes, E. A. (1988). The role of NADH- and NADPH-linked acetoacetyl-CoA reductase in the poly-3-hydroxybutyrate synthesizing organism Alcaligenes eutrophus. FEMS Microbiol Lett 52, 259-264.

Hiser, L. H., Basson, M. E. \& Rine, J. (1993). Acetoacetyl-CoA thiolase gene from Saccharomyces cerevisiae. GenBank accession no. L20428.

Hohn, B. (1979). In vitro packaging of $\lambda$ and cosmid DNA. Methods Enzymol 68, 299-309.

Hohn, B. \& Collins, J. (1980). A small cosmid for efficient cloning of large DNA fragments. Gene 11, 291-298.

Hustede, E. \& Steinbuchel, A. (1993). Characterization of the polyhydroxyalkanoate synthase gene locus of Rhodobacter sphaeroides. Biotechnol Lett 15, 709-714.

Hustede, E., Steinbuchel, A. \& Schlegel, H. G. (1992). Cloning of poly(3-hydroxybutyric acid) synthase genes of Rbodobacter sphaeroides and Rhodospirillum rubrum and heterologous expression in Alcaligenes eutrophus. FEMS Microbiol Lett 72, 285-290.

Kretovich, W. L., Romanov, V. I., Yushkova, L. A., Shramko, V. I. \& Fedulova, N. G. (1977). Nitrogen fixation and poly- $\beta$ hydroxybutyric acid content in bacteroids of Rbizobium lupini and Rbizobium leguminosarum. Plant Soil 48, 291-302.

Kurihara, T., Ueda, M., Kanayama, N., Kono, J., Teranishi, Y. \& Tanaka, A. (1992). Peroxisomal acetoacetyl-CoA thiolase of an $n-$ alkane-utilizing yeast, Candida tropicalis. Eur $J$ Biochem 210, 999-1005.

Liebergesell, M. \& Steinbuchel, A. (1992). Cloning and nucleotide sequences of genes relevant for biosynthesis of poly(3hydroxybutyric acid) in Chromatium vinosum strain D. Eur J Biochem 209, 135-150.

Liebergesell, M. \& Steinbüchel, A. (1993). Cloning and molecular analysis of the poly(3-hydroxybutyric acid) biosynthetic genes of Thiocystis violacea. Appl Microbiol Biotechnol 38, 493-501.

Liebergesell, M., Schmidt, B. \& Steinbuchel, A. (1992). Isolation and identification of granule-associated proteins relevant for poly(3hydroxyalkanoic acid) biosynthesis in Chromatium vinosum D. FEMS Microbiol Lett 78, 227-232.

Mead, D. A., Szczesna Skorupa, E. \& Kemper, B. (1986). Singlestranded DNA 'blue' T7 promoter plasmids: a versatile tandem promoter system for cloning and protein engineering. Protein Eng 1, 67-74.

Meade, H. M., Long, S. R., Ruvkun, G. B., Brown, S. E. \& Ausubel, F. M. (1982). Physical and genetic characterization of symbiotic and auxotrophic mutants of Rbizobium meliloti induced by transposon Tn5 mutagenesis. J Bacteriol 149, 114-122.

Needleman, S. B. \& Wunsch, C. D. (1970). A general method applicable to the search for similarities in the amino acid sequence of two proteins. $J \mathrm{Mol} \mathrm{Biol} \mathrm{48,} \mathrm{443-453.}$

Peoples, O. P. \& Sinskey, A. J. (1989a). Poly- $\beta$-hydroxybutyrate (PHB) biosynthesis in Alcaligenes eutrophus H16. Identification and characterization of the PHB polymerase gene $(p b b C)$. J Biol Chem 264, 15298-15303.

Peoples, O. P. \& Sinskey, A. J. (1989b). Poly- $\beta$-hydroxybutyrate biosynthesis in Alcaligenes eutrophus H16. Characterization of the genes encoding $\beta$-ketothiolase and acetoacetyl-CoA reductase. $J$ Biol Chem 264, 15293-15297.

Peoples, O. P. \& Sinskey, A. J. (1989c). Fine structural analysis of the Zoogloea ramigera $p h b A-p h b B$ locus encoding $\beta$-ketothiolase and acetoacetyl-CoA reductase: nucleotide sequence of $p b b B$. Mol Microbiol 3, 349-357.

Peoples, O. P., Masamune, S., Walsh, C. T. \& Sinskey, A. J. (1987). Biosynthetic thiolase from Zoogloea ramigera. III. Isolation and characterization of the structural gene. J Biol Chem 262, 97-102.

Pieper, U. \& Steinbuchel, A. (1992). Identification, cloning and sequence analysis of the poly(3-hydroxyalkanoic acid) synthase gene of the gram-positive bacterium Rhodococcus ruber. FEMS Microbiol Lett 75, 73-79.

Pieper-Furst, U., Madkour, M. H., Mayer, F. \& Steinbuchel, A. (1994). Purification and characterization of a 14-kilodalton protein that is bound to the surface of polyhydroxyalkanoic acid granules in Rhodococcus ruber. J Bacteriol 176, 4328-4337.

Povolo, S., Tombolini, R., Morea, A., Anderson, A. J., Casella, S. \& Nuti, M. P. (1994). Isolation and characterization of mutants of Rbizobium meliloti unable to synthesize poly- $\beta$-hydroxybutyrate (PHB). Can J Microbiology 40, 823-829.

Prakash, R. K., Hooykaas, P. J. J., Nuti, M. P., Lepidi, A. A., Ledeboer, A. M., Juliot, J. S. \& Dénarié, J. (1980). Detection, isolation and characterization of large plasmids in Rbizobium. In Nitrogen Fixation, vol. II, pp. 136-163. Edited by W. E. Newton \& W. H. Orme-Johnson. Baltimore: Park Press.

Pries, A., Priefert, H., Kruger, N. \& Steinbuchel, A. (1991). Identification and characterization of two Alcaligenes eutrophus gene loci relevant to the poly(beta-hydroxybutyric acid)-leaky phenotype which exhibit homology to ptsH and ptsI of Escherichia coli. $J$ Bacteriol 173, 5843-5853.

Pries, A., Hein, S. \& Steinbuchel, A. (1992). Identification of a lipoamide dehydrogenase gene as second locus affected in poly(3hydroxybutyric acid)-leaky mutants of Alcaligenes eutrophus. FEMS Microbiol Lett 76, 227-233.

Romanov, V. I., Fedulova, N. G., Tchermenskaya, I. E., Shramko, V. I., Molchanov, M. I. \& Kretovich, W. L. (1980). Metabolism of poly- $\beta$-hydroxybutyric acid in bacteroids of Rhizobium lupini in connection with nitrogen fixation and photosynthesis. Plant Soil 56, 379-390. 
Sambrook, J., Fritsch, E. F. \& Maniatis, T. (1989). Molecular Cloning: a Laboratory Manual, 2nd edn. Cold Spring Harbor, NY: Cold Spring Harbor Laboratory.

Schembri, M. A., Bayly, R. C. \& Davies, J. K. (1994a). Cloning and analysis of the polyhydroxyalkanoic acid synthase gene from an Acinetobacter sp: evidence that the gene is both plasmid and chromosomally located. FEMS Microbiol Lett 118, 145-152.

Schembri, M. A., Bayly, R. C. \& Davies, J. K. (1994b). Cloning and molecular analysis of the polyhydroxyalkanoic acid gene locus from an Acinetobacter sp. In Abstracts from the International Symposium on Bacterial PHA, August 14-18, 1994, Montreal, Canada, p. 49.

Schubert, P., Steinbüchel, A. \& Schlegel, H. G. (1988). Cloning of the Alcaligenes eutrophus genes for synthesis of poly-betahydroxybutyric acid (PHB) and synthesis of PHB in Escherichia coli. $J$ Bacteriol 170, 5837-5847.

Selvaraj, G., Fong, Y. C. \& Iyer, V. N. (1984). A portable DNA sequence carring the cohesive site (cos) of bacteriophage $\lambda$ and the mob (mobilization) region of the broad-host-range plasmid RK2: a module for the construction of new cosmids. Gene 32, 235-241.

Senior, P. J. \& Dawes, E. A. (1973). The regulation of poly- $\boldsymbol{\beta}$ hydroxybutyrate metabolism in Azotobacter beijerinckii. Biochem $J$ 134, 225-238.

Shin, Y. Y., Hiraishi, A. \& Sugiyama, J. (1993). Molecular systematics of the genus Zoogloea and emendation of the genus. Int J Syst Bacteriol 43, 826-831.

Simon, R., Priefer, U. \& Puhler, A. (1983). A broad host range mobilization system for in vivo genetic engineering: transposon mutagenesis in gram negative bacteria. Bio/Technology 1, 784-791.

Slater, S. C., Voige, W. H. \& Dennis, D. E. (1988). Cloning and expression in Escherichia coli of the Alcaligenes eutrophus H16 polybeta-hydroxybutyrate biosynthetic pathway. $J$ Bacteriol 170, 4431-4436.

Spaink, H. P., Okker, R. J. H., Wijffelman, C. A., Pees, E. \& Lugtenbergs, B. J. J. (1987). Promoters in the nodulation region of the Rbizobium leguminosarum Sym plasmid pRL1 JI. Plant Mol Biol 9 , 27-39.

Steinbuchel, A. (1991). Polyhydroxyalkanoic acids. In Biomaterials. Novel Materials from Biological Sources, pp. 123-213. Edited by D. Byrom. New York: Macmillan \& ICI Biological Products.

Steinbuchel, A., Hustede, E., Liebergesell, M., Pieper, U., Timm, A. \& Valentin, H. (1992). Molecular basis for biosynthesis and accumulation of polyhydroxyalkanoic acids in bacteria. FEMS Microbiol Rev 9, 217-230.

Tombolini, R. \& Nuti, M.P. (1989). Poly( $\beta$-hydroxyalkanoate) biosynthesis and accumulation by different Rbizobium species. FEMS Microbiol Lett 60, 299-304.

Valentin, H. E. \& Steinbuchel, A. (1993). Cloning and characterization of the Metbylobacterium extorquens polyhydroxyalkanoic acid synthase structural gene. Appl Microbiol Biotechnol 39, 309-317.

Vollack, K. U., Bach, T. J. \& Kai-Uwe, U. (1994). Isolation and characterization of a cDNA encoding a plant acetoacetyl-CoA thiolase by functional complementation in yeast. GenBank accession no. X78116.

Wong, P. P. \& Evans, H. J. (1971). Poly- $\beta$-hydroxybutyrate utilization by soybean (Glycine max Merr.) nodules and assessment of its role in maintenance of nitrogenase activity. Plant Pbysiol 47, 750-755.

Yang, S.-Y., Yang, X.-Y. H., Healy-Louse, G., Schulz, H. \& Elzinga, M. (1990). Nucleotide sequence of the $\mathrm{fad} A$ gene : primary structure of 3-ketoacyl-coenzyme A thiolase from Escherichia coli and the structural organization of $\mathrm{fad} A B$ operon. $J$ Biol Chem 265, 10424-10426.

Yanisch-Perron, C., Vieira, J. \& Messing, J. (1985). Improved M13 phage cloning vectors and host strains: nucleotide sequences of the M13mp18 and pUC19 vectors. Gene 33, 103-119.

Received 18 January 1995; revised 23 May 1995; accepted 2 June 1995. 